\title{
APRESENTAÇÃO
}

\section{EDUCAÇÃO INTEGRAL: DIVERSIDADE, POLÍTICAS E PRÁTICAS}

\author{
Débora Mazza \\ Adriana Varani ${ }^{1}$ (1) \\ Nima Imaculada Spigolon ${ }^{1}$ (1) \\ Elizabeth Rossin ${ }^{1}$
}

$\mathrm{N}$

osso ponto de partida compreende que dialogar com a Educação Integral impóe uma inescapável articulação entre os campos da pesquisa, da política educacional e, sobretudo, da práxis, momento em que se confronta o cumprimento das normas, burocracias reificadas nos planos, diretrizes com o cotidiano da escola, lugar onde pulsa vida, relaçóes sociais e humanas.

Nesse contexto, a implementação da educação em tempo integral, conforme preconiza o Plano Nacional de Educação/2014 (PNE) (BRASIL, 2014), suscita, no movimento do real, reconhecer as experiências e os posicionamentos precedentes que marcaram os fazeres e os saberes da Educação Integral, mediados inicialmente por um tempo maior de permanência no cotidiano escolar. Como o passado elabora as açóes do presente, faz jus o registro de iniciativas brasileiras dos educadores Anísio Teixeira (2007), Darcy Ribeiro (1986), da concepção socialista de educação na Revolução Russa por Pistrak (2013), entre outros projetos de caráter emancipatório nas políticas educacionais em que os espaços e os tempos comparecem dando significado na atividade humana para a formação do sujeito integral.

Entrementes, em tempos atuais, para defesa de um projeto societário burguês excludente, o Estado brasileiro, em seu aparato antidemocrático, extirpa as conquistas das políticas públicas, retirando não só os direitos forjados nas lutas sociais, mas o sentido da formaçáo humana integral, intrínseco à

\footnotetext{
${ }^{1}$ Universidade Estadual de Campinas - Campinas (SP), Brasil. E-mails: dmazza@unicampp.br, nima@unicamp.br, avarani@unicamp.br, bethrossin@gmail.com
}

DOI: $10.1590 / C C 0101-32622019218756$ 
educação (ARROYO, 2017). Portanto, essas múltiplas determinaçóes da realidade social nos instigam a debater a dimensão da educação em tempo integral e sua integralidade para a formaçáo humana no reconhecimento das multidimensionalidades para a constituição de sujeitos críticos, para além da ampliação da jornada escolar. Nesse sentido, em um campo de disputas ideológicas e de contradiçóes, fazem-se imperiosos posicionamentos éticos-políticos em defesa de uma educação que tem como perspectiva a emancipação humana.

Desse modo, conceber a educação na integralidade do tempo e da formação humana nos impulsiona trabalhar com radicalidade analítica qual a sua finalidade. Uma escola de educação integral para quem e para quê? Fundada em quais conceitos: formação humana integral a partir das referências da necessária emancipação humana? Assim, é fundante a tessitura de diálogos engendrados nas narrativas expressas pelas e com as vozes dos professores e dos alunos, a partir da realidade miúda do cotidiano da escola e, ainda, das produçóes acadêmicas que, com rigor, abordam a tão complexa educação integral e suas tramas polifônicas de conceitos.

Os artigos que compóem este dossiê carregam, pois, a diversidade temática sobre a Educação Integral a que vimos nos referindo. Eles estão alinhados com a intencionalidade de ampliação do debate sobre a Educaçáo Integral e nela adentrar para reconhecer sua complexidade, produzindo sentidos para a criação de políticas e práticas.

Iniciamos um debate provocativo sobre o tempo livre não institucionalizado que circula entre as esferas formais e não formais da escola no Brasil e em Portugal, lá denominado de "Escola a Tempo Inteiro", no artigo "Educaçáo integral e institucionalizaçáo do tempo livre: outras lógicas educacionais no contexto Luso-Brasileiro", assinado pelos autores Juliana Pedreschi Rodrigues, José Luís Gonçalves, Valéria Aroeira Garcia e Daniela Gonçalves. Esse artigo vem encadear um diálogo atual entre peculiaridades das propostas de educação integral em ambos os países, a partir da premissa de que se faz necessário atentarmos para outros jeitos de organizar o processo educacional, escapando de uma única lógica e da institucionalização do tempo livre.

$\mathrm{Na}$ sequência, as autoras Crislaine Matozinhos Silva Modesto, Débora Mazza e Nima Imaculada Spigolon nos convocam a refletir com o artigo "A formação humana integral diante de retrocessos sociais", em que problematizam os desafios da educaçáo brasileira, na concepção da formação humana 
integral, a partir da Emenda Constitucional (EC) no 95/2016, que institui um novo regime fiscal para as despesas sociais nos próximos 20 anos, provocando consequências irreversíveis às políticas públicas e, especialmente, à educação.

$\mathrm{E}$ as inquietações não cessam quando o debate da educação integral e formação humana circulam as práticas pedagógicas. $\mathrm{O}$ artigo intitulado "A formação humana integra a educação integral? O que as práticas pedagógicas têm a nos dizer”, das autoras Adriana Varani, Cristina Maria Campos e Elizabeth Rossin, propóe, a partir da experiência com alfabetização e suas contradiçóes, debater a formação humana no contexto da educação integral em uma perspectiva emancipatória.

E no diálogo com o "chão da escola", o artigo "Escola de tempo integral $\times$ formação humana integral: experiências de uma EEI no município de Campinas”, elaborado por Elaine Cristina Panini Messa, Juliana Cristina Chaves Buldrin Baiocchi, Renato Horta Nunes e Simone Cecilia Fernandes, socializa práticas educativas pondo em análise o conceito de Educação Integral na perspectiva da formação humana, provocando reflexões e narrativas que mobilizam o jeito de ver e fazer o trabalho educativo.

Em face das requisiçóes institucionais para efetivação do tempo integral nas escolas, o artigo intitulado "Ampliação da jornada das escolas públicas brasileiras: um panorama de políticas e discursos", das autoras Patrícia Peixoto Zapletal e Adriana Marcondes Machado, apresenta um estudo bibliográfico sobre a ampliação da jornada escolar no Brasil, no qual encontra argumentos daqueles que justificam as propostas da escola de tempo integral e os que questionam as adesóes acríticas acerca das reformas educacionais.

Nessa esteira de análise, faz-se mister ir à raiz dos elementos fundantes e debater "os tempos" na educação integral, o que é proposto por Mariana Roveroni, Adriana Missae Momma e Bruna Cirino Guimarães no artigo "Educaçáo integral, Escola de tempo integral: um diálogo sobre 'os tempos", convidando-nos a refletir sobre as contradiçóes das iniciativas, a partir de experiências da rede municipal de Campinas e seus modos de fazer e resistir.

Fundamentado no cotidiano das escolas e no contexto educacional, coloca-se em discussão a relação entre as políticas de Educação Integral e Educação Especial no artigo "Educação integral e Atendimento educacional especializado: como essas políticas são implementadas ao mesmo tempo?”, de Mariana da Cunha Sotero, Eliana Briense Jorge 
Cunha e Valéria Aroeira Garcia. As autoras questionam quais tempos e espaços têm se estabelecido entre o Atendimento Educacional Especializado (AEE) e a implementação da Educação Integral, tendo em vista conciliar as necessidades de crianças e adolescentes da educação especial.

Por fim, e consubstanciando esse dossiê, apresentamos a entrevista inédita intitulada "Anísio Teixeira - dilemas educacionais e políticos do seu e do nosso tempo", realizada por Jaqueline Moll com as Profas. Ana Waleska Mendonça (falecida em 2017) e Libânia Xavier. Entre os temas abordados: PNE de 1962, formação de professores, prolongamento do tempo escolar, Educação Integral, experiências pedagógicas, diálogo com Darcy Ribeiro e outros. Os temas criam interfaces com a atualidade, na perspectiva anisiana de que os intervalos democráticos vividos no Brasil não permitiram a consolidação de um sistema educacional universal e de qualidade.

E assim sendo, a originalidade e a relevância político-pedagógica do dossiê se espraiam na diversidade das produçóes dos autores e das autoras que mapeiam essa discussão. Os textos mediam as políticas, as traduçóes, os fazeres e os saberes no campo interdisciplinar dos conhecimentos acadêmicos, no horizonte da emancipação humana.

\section{REFERÊNCIAS}

ARROYO, M. O direito à formação humana como referente da avaliação. In: DE SORDI, M.R. (org.). Qualidade(s) da escola pública: reinventando a avaliaçâo como resistência. Uberlândia: Navegando, 2017.

BRASIL. Presidência da República. Plano Nacional de Educação (2014-2024). Lei no 13.005, 25 de junho de 2014. Brasília, 2014.

PISTRAK, Moisey M. A escola-comuna. São Paulo: Expressão Popular, 2013. RIBEIRO, Darcy. O livro dos CIEPS. Rio de Janeiro: Editora Bloch, 1986. TEIXEIRA, A. Educação não é privilégio. 7. ed. Rio de Janeiro: Editora UFRJ, 2007.

Recebido em 20 de março de 2019.

Aprovado em $1^{\circ}$ de julho de 2019.

(C) 2019 Centro de Estudos Educação e Sociedade - CEDES Este é um artigo de acesso aberto distribuído nos termos de licença Creative Commons.

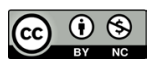

